\title{
Direct and indirect surface geochemical methods in petroleum exploration: a case study from eastern part of the Polish Outer Carpathians
}

\author{
Henryk Sechman ${ }^{1}$ [ $\cdot$ Piotr Guzy $^{1} \cdot$ Paulina Kaszuba $^{1} \cdot$ Anna Wojas $^{1} \cdot$ Grzegorz Machowski $^{1} \cdot$ Anna Twaróg ${ }^{1}$. \\ Adrianna Maślanka ${ }^{1}$
}

Received: 25 November 2019 / Accepted: 4 May 2020 / Published online: 20 May 2020

(c) The Author(s) 2020

\begin{abstract}
The objective of this paper is to evaluate the relationship between the distributions of direct and indirect, surface geochemical indices in the selected part of the Outer Carpathians. The research included analysis of molecular composition of soil gas samples and calcite contents as well as the measurements of magnetic susceptibility and $\mathrm{pH}$ of soil samples. The survey contained 96 soil gas samples collected from $1.2 \mathrm{~m}$ depth and 96 soil samples taken from interval $0.7-0.8 \mathrm{~m}$ depth. The maximum concentrations of methane, total alkanes $\mathrm{C}_{2}-\mathrm{C}_{5}$ and total alkenes $\mathrm{C}_{2}-\mathrm{C}_{4}$ were: $2100,10.43$ and $0.772 \mathrm{ppm}$. The magnetic susceptibility values changed from 3.6 to $21.5 \times 10^{-8} \mathrm{~m}^{3} / \mathrm{kg}$. The calcium carbonate contents varied from 0.02 to $29.92 \mathrm{wt} \%$ and the $\mathrm{pH}$ values measured in soil solutions obtained changed from 4.5 to 8.3. Although the results demonstrate no correlation between the direct soil gas anomalies and the indirect geochemical indicators, the integrated profiles in Fig. 7 suggest possible haloes in the calcite/magnetic data that could be related to hydrocarbons migrating from depth. There are, however, various independent mechanisms that might control the appearance of these mineral anomalies. Secondary changes of mineral composition of soils disclosed by the indirect methods, even if controlled by hydrocarbon migration throughout geological time, might cause some closure of migration pathways, influencing the location of active hydrocarbon migration pathways. Comprehensive interpretation of the results obtained by direct and indirect methods in this paper provides another positive example helping to better understand the complicated mechanism of hydrocarbon migration and the potential usefulness of indirect methods suitable for hydrocarbon exploration.
\end{abstract}

Keywords Soil gas $\cdot$ Light alkanes $\cdot$ Magnetic susceptibility $\cdot$ Calcium carbonate contents $\cdot$ Outer Carpathians

\section{Introduction}

Many world petroleum provinces, which host conventional petroleum deposits, reveal much higher hydrocarbon potential confirmed by the discovery and the assessment of unconventional deposits: shale gas, shale oil, tight gas and tight oil (Boyer et al. 2011; Zou 2013; U.S. EIA 2019). Moreover, a significant potential may be provided by so-called "hybrid" hydrocarbon accumulations. These objects integrate the features of both the conventional and the unconventional plays

Henryk Sechman

sechman@agh.edu.pl

1 Faculty of Geology, Geophysics and Environmental Protection, AGH University of Science and Technology, Al. Mickiewicza 30, 30-059 Kraków, Poland
(Kozimor et al. 2017). According to Kozimor et al. (2017), such accumulations may occur, among others, in the Carpathian Foredeep and in the Outer Carpathians belonging to the Małopolska Petroleum Province of southern Poland (Karnkowski 2007). That is why the Polish part of the Outer Carpathians is still regarded as a promising target of petroleum exploration, despite its 150 -year-long history of discovery and exploitation of hydrocarbon deposits (Kuśmierek 1990; Dziadzio et al. 2006; Pawlewicz 2006; Ślączka et al. 2006; Karnkowski 2007).

Recently, the petroleum exploration methodology is dominated by geophysical methods, particularly by the reflection seismic. However, although still improving, this method shows limitations due to insufficient quality of seismic records caused by fold-and-thrust structure of the Carpathian orogenic belt (Roure et al. 1993; Pawlewicz 2006; Kuśmierek 2010; Kuśmierek and Baran 2016; Kováč et al. 
2017). Moreover, the Carpathian petroleum system is exceptionally complicated, similar to other orogenic belts where petroleum exploration projects were or are currently in operation (Kuśmierek 1990; Dziadzio et al. 2006; Matyasik and Dziadzio 2006; Kotarba and Koltun 2006; Kotarba et al. 2007; Karnkowski and Matyasik 2016). According to Karnkowski and Matyasik (2016), one of the important elements of any petroleum system is the hydrocarbon migration pattern, which strongly affects both the formation and the preservation of petroleum accumulations. Hence, the application of other, independent methods is crucial to the improvement of geological and deposit models. One method commonly applied in petroleum exploration is the surface geochemical survey. Its skillful integration with other, geological and seismic methodologies enables the reduction of the risk related by location of negative exploratory wells (Schumacher 2017). The surface geochemical survey includes many detailed methods among which the most popular is the "soil gas" method, which allows determination of light, saturated and unsaturated hydrocarbons, as well as non-hydrocarbon components (helium, hydrogen) present in the near-surface zone (Klusman 1993; Tedesco 1995; Matthews 1996; Saunders et al. 1999; Jones et al. 2000; Harbert et al. 2006; Sechman 2012; Sechman et al. 2012, 2015, 2016, 2018; Twaróg et al. 2018b). Changes of trace concentrations of hydrocarbons in the near-surface zone produce geochemical anomalies, which may indicate the presence of deep-seated accumulations. Moreover, geochemical survey provides valuable information about current hydrocarbon migration system from depths to the Earth's surface. Apart from the soil gas method, which belongs to direct surface geochemical methods, many researchers have developed the indirect geochemical methodologies, which record some physical and chemical changes in rock formations caused by hydrocarbon migration to the surface (Klusman 1993; Tedesco 1995; Matthews 1996; Saunders et al. 1999; Schumacher 1996; Wolleben and Greenlee 2002; LeSchack and van Alstine 2002). For instance, it was found that some mineralogical changes in the near-surface zone are related to the deep hydrocarbon accumulations (Elmore et al. 1987; Sassen et al. 1989; Reynolds et al. 1990). Such supplementary information about analyzed prospects is useful for decisions about locating of new wells. World literature provides many examples of geochemical survey results applied in petroleum exploration (Klusman 1993; Tedesco 1995; Liu et al. 2004; Twaróg et al. 2018a). Among indirect geochemical methods, attention must be paid to measurements of magnetic susceptibility and analyses of calcium carbonate contents in soils. Many publications have demonstrated the relationships between the hydrocarbons migrating from deep accumulations and the formation of magnetic minerals (Sassen et al. 1989; Machel and Burton 1991; Gay 1992; Saunders et al. 1991) as well as the presence secondary cementation zones by calcium carbonate (Donovan 1974; Schumacher 1996; Mørk et al. 2001).

However, it must be emphasized that the results of surface geochemical survey, not integrated with the seismic data, will never be sufficient to undertake the successful hydrocarbon exploration projects. Only the analysis and interpretation of integrated, geological, seismic and geochemical models will provide a comprehensive dataset enabling the reasonable localization of exploratory wells.

One of the most promising petroleum prospects in the Polish part of Outer Carpathians, potentially hosting both the conventional and unconventional hydrocarbon accumulations, is the central part of the Central Carpathian Synclinorium of the Silesian Nappe (Kuśmierek et al. 2016a, b) (Fig. 1). In that area, our experimental geochemical research has been carried on, aiming to evaluate the relationships between the distributions of direct and selected indirect, surface geochemical indices. These geochemical indices integrated with the geological and seismic models will enable the researcher to evaluate the presence of hydrocarbon accumulations at depth.

\section{Outline of geological setting of study area}

The Central Carpathian Synclinorium, also known as the Central Carpathian Depression and, in its western part, as the Jasło Synclinorium (Oszczypko et al. 2008) is a geostructural element built of the Silesian Nappe. Its length reaches about $140 \mathrm{~km}$ along the strike and its lithology includes mostly the sediments of the Menilite-Krosno Series (Ślączka et al. 2006 and references therein).

The Central Carpathian Synclinorium is built mostly of the Oligocene Krosno Beds accompanied by the Menilite and the Transitional beds (Figs. 2, 3) (Ślączka et al. 2006).

In the Krosno-Besko geochemical survey area, geological map shows only the sediments of the Menilite-Krosno Series (Starzec 2016) of estimated total thickness from 2000 to 2400 m (Jucha 1969; Kuśmierek 1990).

The Menilite-Krosno Series is dominated by the Krosno Beds lithofacies, which is traditionally subdivided into the: (i) Lower Krosno Beds (thick-bedded sandstones with thin intercalations of shales and mudstones), (ii) Middle Krosno Beds (medium- and thin-bedded sandstones with shales and mudstones interbeds-this is the thickest subunit in the study area) and (iii) Upper Krosno Beds (clayey and marly shales with some intercalations of thin-bedded sandstones) (Fig. 2) (Jucha 1969).

Lithological boundaries within the Menilite-Krosno Series are diachronous, as documented by the position of the Jasło Limestones (Shales) (Fig. 2), which separate the Oligocene sediments into the two complexes: Sub- and Supra-Jasło (Jucha 1969). 


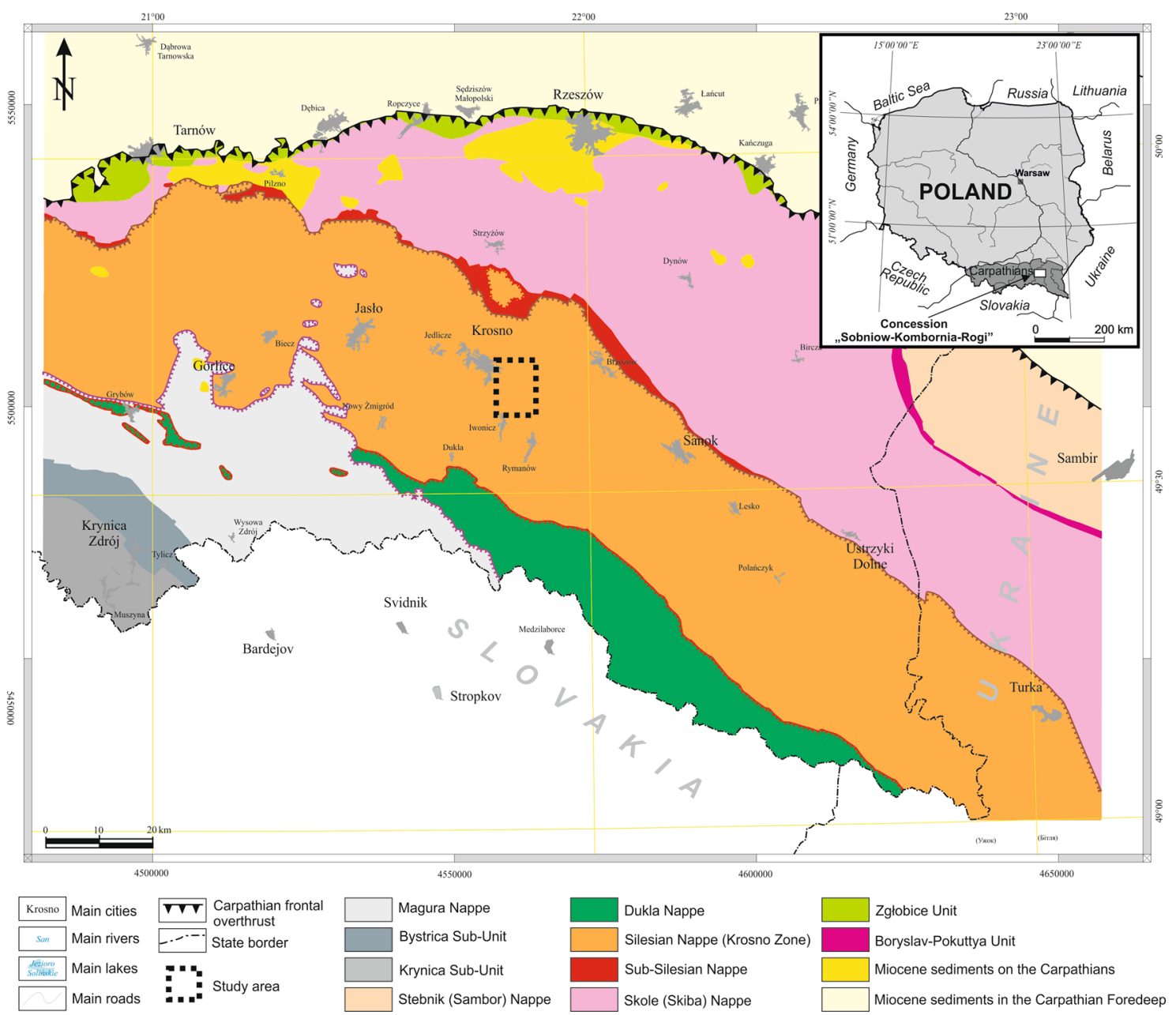

Fig. 1 Geological-structural map of the eastern part of Polish Carpathians with the Krosno-Besko study area (modified, based on Żytko et al. 1989; Jankowski et al. 2004)

\section{Scope and methodology of field works and laboratory analyses}

The study area is located within the exploration concession area "Sobniów-Kombornia-Rogi" owned by the Polish Oil and Gas Co. A fragment of that concession, in which our project was run, is the "Krosno-Besko" sub-area. Geochemical survey was carried on along a $10-\mathrm{km}$-long fragment one of the seismic profiles completed within this concession area (Fig. 2).

\section{Field geochemical survey}

The sampling sites of soil gas were located at $100 \mathrm{~m}$ spacing along the selected seismic profile positioned perpendicularly to the general strike of geological structures in the area (Fig. 2). Soil gas was sampled with the specialized geochemical probe, gas-tight syringe and sample vessel. Geochemical probe was driven into the soil down to $1.2 \mathrm{~m}$ depth. Then, soil gas was drawn with the gas-tight syringe and transferred into the special sample vessel. Detailed methodology of geochemical sampling can be found in previous publications (Sechman and Dzieniewicz 2009; Sechman et al. 2012, 2015). A total of 96 soil gas samples were taken, all under stable weather conditions. Additionally, at the same sampling sites, soil samples were collected from 0.7 to $0.8 \mathrm{~m}$ depth interval using an Egner's soil sampler.

\section{Laboratory analyses of molecular composition of soil gas samples}

The soil gas samples were analyzed chromatographically for light hydrocarbons of paraffin series (methane, ethane, propane, $i$-butane, $n$-butane, $i$-pentane, neo-pentane and $n$-pentane) and gaseous alkenes (ethylene, propylene and 1-butene). Analyses were carried on with Fissons Instruments GC8160 instrument. Hydrogen and carbon dioxide were analyzed with Carlo Erba Instr. device. Interpretation 


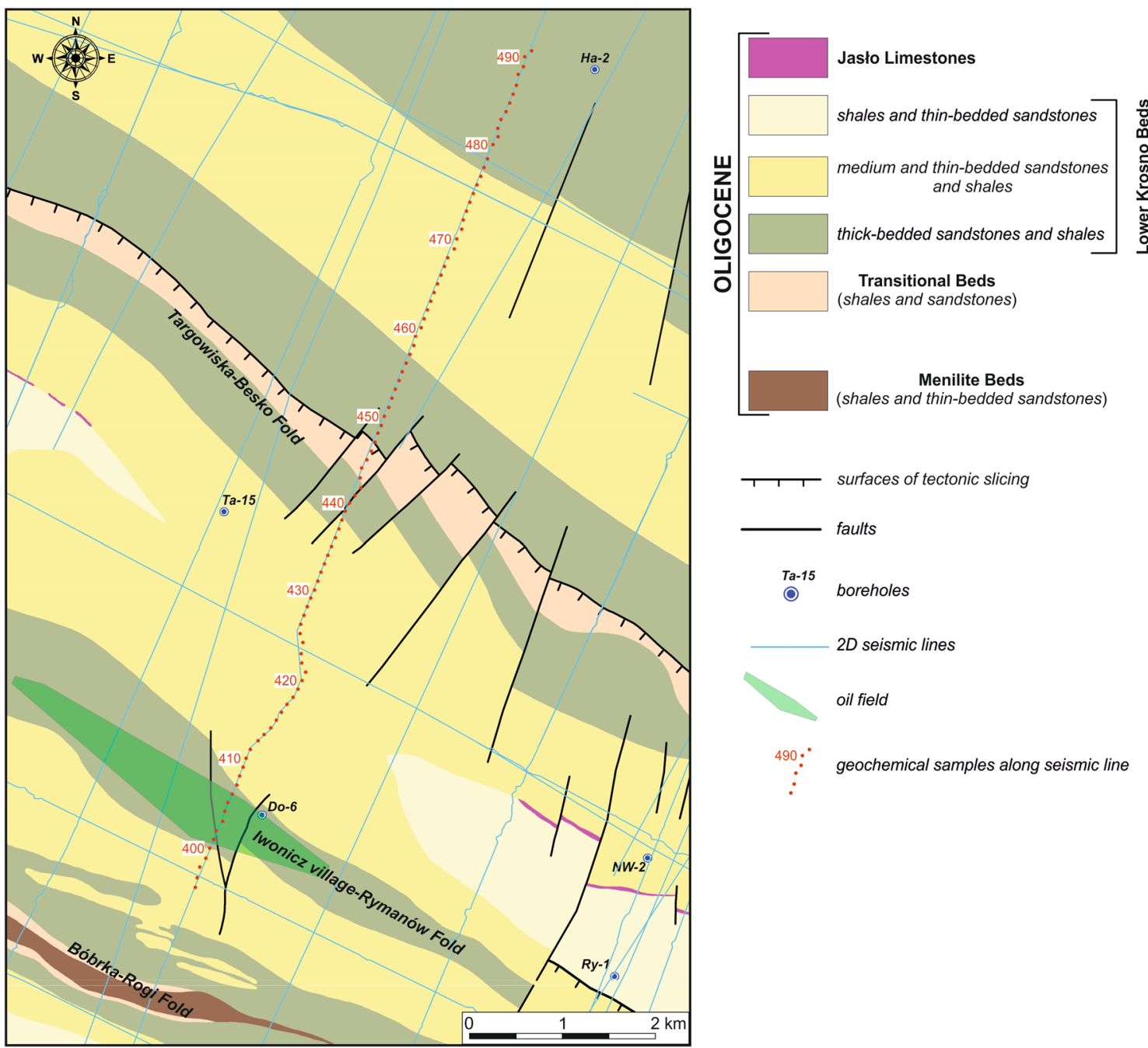

Fig. 2 Distribution of sampling sites against geological map after Starzec (2016), modified

of the results was run with the internal standard method based upon the analogies to calibration gases supplied by Supleco, Alltech and BOC, at the error $\pm 2 \%$. Hydrocarbon detection limit for FID was $0.01 \mathrm{ppm}$, hydrogen and carbon dioxide detection limits for TCD were $0.001 \mathrm{vol} \%$ each. Detailed analytical conditions and parameters of gas chromatography were described in previous publications (Sechman et al. 2012).

\section{Laboratory analyses of calcium carbonate in soil samples}

Contents of calcium carbonate (calcite) were measured in soil samples using the Scheibler's volumetric method. Sample preparation included grinding in a mortar followed by drying at room temperature and sieving on $2 \mathrm{~mm}$ sieve. Before analyses, samples were tested for intensity of $\mathrm{HCl}-\mathrm{CaCO}_{3}$ reaction by pouring of $10 \% \mathrm{HCl}$ solution into about $2 \mathrm{~g}$ of soil, to establish the proper weight of analyzed soil portions. Following the principle that more vigorous reaction results in smaller portion of soil needed for analysis, the weights of particular portions were selected from the range of 1-10 g. Such portions were loaded into a reaction vessel equipped with a small internal box filled with $10 \%$ $\mathrm{HCl}$ solution. Then, the vessel was tightly closed, sample was poured with the acid, and the vessel was shaken. When the reaction was completed the vessel was connected to a graduated measuring tube, to which the carbon dioxide produced during the reaction was transferred. The measuring tube was filled with $5 \% \mathrm{CuSO}_{4}$ solution, which does not react with the $\mathrm{CO}_{2}$. Due to communicating vessels effect, the $\mathrm{CuSO}_{4}$ solution was removed from the measuring tube to the buffer bottle simultaneously with the $\mathrm{CO}_{2}$ inflowing into the measuring tube. After levelling the solutions in the measuring tube and in the buffer bottle, the volume of $\mathrm{CO}_{2}$ was recorded (in $\mathrm{cm}^{3}$ ). Additionally, for each analysis, 


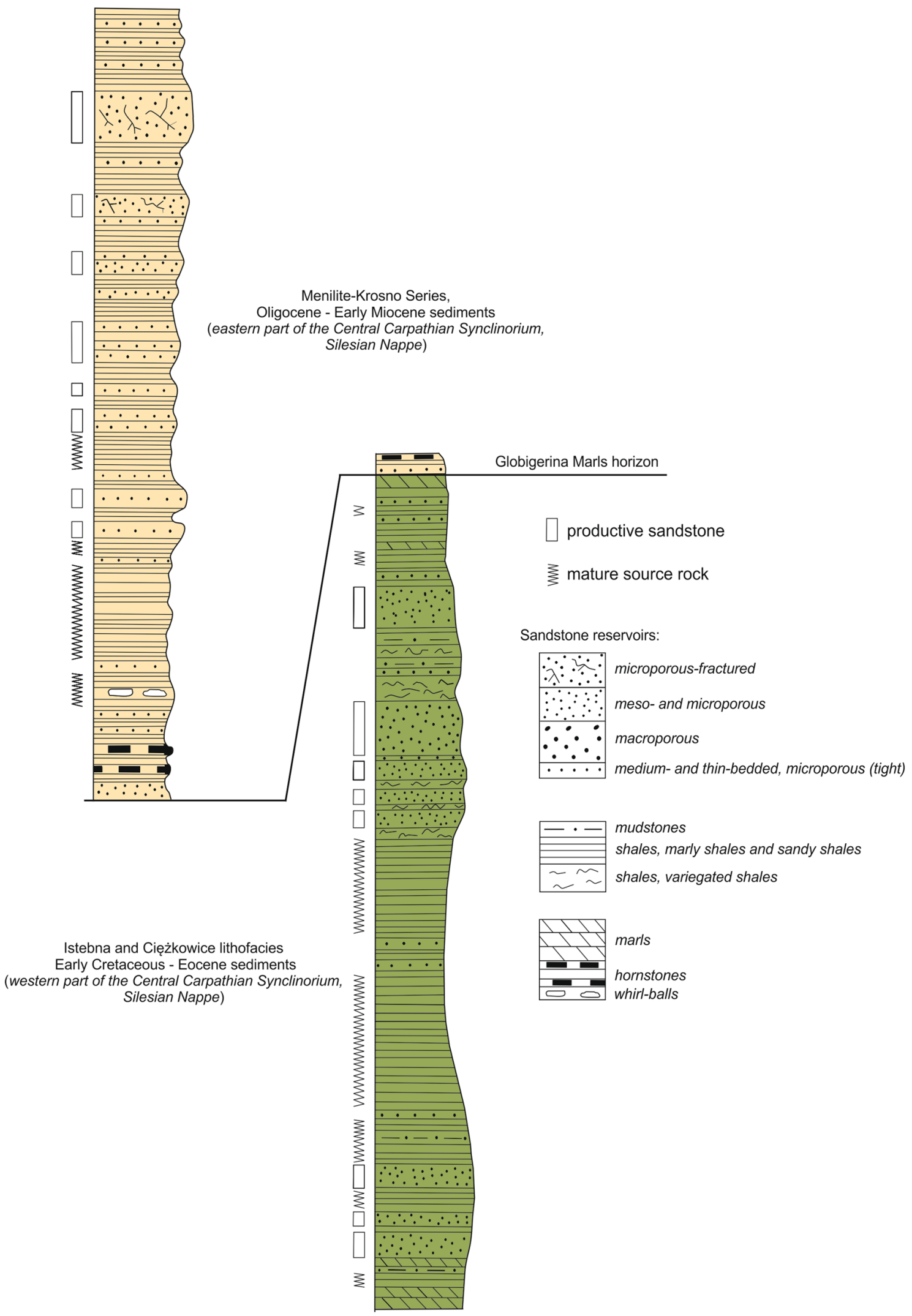

Fig. 3 Selected lithostratigraphic columns of petroleum lithofacies from the Eastern Polish Carpathians (after Kuśmierek and Machowski (2008), modified) 
temperature and air pressure were measured in the laboratory room.

\section{Laboratory pH measurements in soil samples}

For $\mathrm{pH}$ measurements, samples were prepared similarly to those used for $\mathrm{CaCO}_{3}$ analyses, i.e. samples were grinded in a mortar, then dried at room temperature and sieved on $2 \mathrm{~mm}$ sieve. Measurements were carried on in suspension, i.e. soil samples were added with the distilled water 1:5, then the mixture was shaken in a magnetic stirrer for $5 \mathrm{~min}$. and left for next $2 \mathrm{~h}$. Then, measurements were run with the Elmetron's CPC-401 instrument equipped with IJ44C electrode and applying the automatic temperature compensation. Accuracy of readings was 0.1 s.u. (standard units). For each sample, four measurements were executed and their values were accepted as stable if the readings did not change more than 0.02 during $5 \mathrm{~s}$. The final $\mathrm{pH}$ value was the mean calculated from reading No. 2, 3 and 4.

\section{Laboratory measurements of magnetic susceptibility}

The soil samples used for magnetic susceptibility measurements were grinded in a mortar, then dried at the room temperature and sieved on $1 \mathrm{~mm}$ sieve. Such prepared samples were loaded into specialized non-magnetic vessels, $10 \mathrm{~cm}^{3}$ each. Measurements were run with the MS2 instrument equipped with MS2B sensor, similarly to previous studies (Wojas 2009, 2017; Wojas et al. 2010). The analytical manual included: measurement of an empty sensor (i.e. air) followed by measurement of a coil loaded with sample and again, measurement of an empty sensor. For each sample, five measurements were completed and the results were averaged. To determine the mass magnetic susceptibility, samples were weighted with the analytical balance.

\section{Results and discussion}

\section{Statistical characterization of measured concentrations of gaseous components in soil gas samples}

The measured methane concentrations differ by three orders of magnitude and reach maximum value of $2100 \mathrm{ppm}$. Moreover, this dataset shows arithmetic mean one order of magnitude higher than the median and the relatively high standard deviation (Table 1), which documents the presence of methane anomalies along the sampling line. The proportion of samples in which concentrations of particular alkanes exceed detection limit of an instrument decrease with the increasing number of atoms in molecules (Table 1). This indicates deep source of hydrocarbons detected in soil gas (Sokolov and Grigoriev 1962; Jones and Drozd 1983; Harbert et al. 2006; Sechman et al. 2012, 2015, 2016, 2018; Twaróg et al. 2018b). Usually, the increasing concentrations of methane are followed by the same trend in concentrations of its higher homologues. However, in some samples, higher methane concentrations were not accompanied by those of higher homologues, which indicates the presence of microbial methane, generated in the near surface zone.

In $62.5 \%$ of analyzed samples, ethane concentrations exceeded the FID detection limit. Similar to methane, the mean ethane concentration was one order of magnitude higher than its median (Table 1). Propane was detected in almost $43 \%$ of analyzed samples with the maximum value up to $3.2 \mathrm{ppm}$. Both the $i$-butane and $n$-butane were found in almost $20 \%$ and over $29 \%$ of analyzed samples, respectively. Average $n$-butane concentration was exactly three times higher than that of $i$-butane. Similar relationship was observed for maximum concentrations of both compounds. Maximum concentrations of $i$-pentane and $n$-pentane were also similar (Table 1).

Table 1 Principal statistical parameters of alkane concentrations in analyzed soil gas samples

\begin{tabular}{|c|c|c|c|c|c|c|c|c|c|}
\hline \multirow[t]{2}{*}{ Statistical parameters } & \multicolumn{8}{|c|}{ Alkanes } & \multirow{2}{*}{$\begin{array}{l}\text { Total } \\
\text { alkanes } \\
\mathrm{C}_{2}-\mathrm{C}_{5}\end{array}$} \\
\hline & $\mathrm{CH}_{4}$ & $\mathrm{C}_{2} \mathrm{H}_{6}$ & $\mathrm{C}_{3} \mathrm{H}_{8}$ & $i \mathrm{C}_{4} \mathrm{H}_{10}$ & $n \mathrm{C}_{4} \mathrm{H}_{10}$ & neo- $\mathrm{C}_{5} \mathrm{H}_{12}$ & $i \mathrm{C}_{5} \mathrm{H}_{12}$ & $n \mathrm{C}_{5} \mathrm{H}_{12}$ & \\
\hline Minimum (ppm) & 1.1 & b.d.1 & b.d.l & b.d.1 & b.d.1 & b.d.1 & b.d.1 & b.d.1 & b.d.1 \\
\hline Maximum (ppm) & 2100.0 & 4.29 & 3.19 & 0.46 & 1.47 & 0.018 & 0.457 & 0.572 & 10.4 \\
\hline Median (ppm) & 2.2 & 0.013 & b.d.l & b.d.1 & b.d.1 & b.d.l & b.d.l & b.d.l & 0.023 \\
\hline Mean (ppm) & 26.8 & 0.181 & 0.125 & 0.019 & 0.057 & 0.0004 & 0.018 & 0.022 & 0.423 \\
\hline Standard deviation (ppm) & 213.7 & 0.561 & 0.428 & 0.069 & 0.202 & 0.002 & 0.068 & 0.081 & 1.400 \\
\hline Skewness (ppm) & 9.8 & 5.546 & 5.515 & 4.683 & 5.319 & 6.158 & 4.768 & 5.213 & 5.434 \\
\hline Percentage of samples $(\%)^{\mathrm{a}}$ & 100.0 & 62.5 & 42.7 & 19.8 & 29.2 & 4.2 & 12.5 & 18.75 & 70.8 \\
\hline
\end{tabular}

b.d.l. below detection limit

${ }^{\text {a }}$ Percentage of samples with concentration of given component over detection limit 
The concentrations of total alkanes $\mathrm{C}_{2}-\mathrm{C}_{5}$ above the FID detection limit were observed in almost $71 \%$ of analyzed samples with the maximum value of $10.4 \mathrm{ppm}$, the mean value one order of magnitude higher than the median and the relatively high standard deviation. All these parameters indicate significant share of anomalous concentrations of total alkanes $\mathrm{C}_{2}-\mathrm{C}_{5}$ (Table 1).

Among unsaturated hydrocarbons, the most common was ethylene, which was detected in almost $60 \%$ of analyzed samples. Its maximum value was $0.65 \mathrm{ppm}$ and its average concentration was over 4 times higher than the median. Higher alkenes homologues were found in only trace in about $65 \%$ of analyzed samples (Table 2). Maximum concentration of total alkenes $\mathrm{C}_{2}-\mathrm{C}_{4}$ was $0.77 \mathrm{ppm}$ and the average value was $0.064 \mathrm{ppm}$.

Comparison of total alkanes $\mathrm{C}_{2}-\mathrm{C}_{5}$ and total alkenes $\mathrm{C}_{2}-\mathrm{C}_{4}$ concentrations revealed the dominance of alkanes in both the datasets and in the other statistical parameters (Tables 1,2). The differences were particularly distinct for maximum and mean concentrations, as the maximum concentration of total alkanes $\mathrm{C}_{2}-\mathrm{C}_{5}$ was two orders of magnitude higher than that of total alkenes $\mathrm{C}_{2}-\mathrm{C}_{4}$. For mean values, this difference was one order of magnitude.

The relationships between ethane and ethylene as well as propane and propylene were used by some authors to evaluate the relative migration activeness of alkanes, because the appearance of relatively higher amounts of ethylene and propylene may result from both the biological and the chemical oxidation of a part of ethane and propane quantities migrating from deep petroleum accumulations (Telegina and Cherkinskaya 1971; Klusman 1993, 2006, 2011; Saunders et al. 1999; Jones et al. 2000; Harbert et al. 2006; Sechman 2012; Sechman et al. 2012). According to Saunders et al. (1999), the relatively rapid migration of molecules along fractures and faults does not leave sufficient time for significant oxidation of alkanes to alkenes. Thus, high ratio (over 3 ) of saturated to unsaturated hydrocarbons may indicate relatively fast migration from deep accumulations towards the surface
(Saunders et al. 1999; Jones et al. 2000; Harbert et al. 2006; Sechman 2012; Sechman et al. 2012). Taking into account both the similar compaction of sediments and the similar permeability of the overburden, such active migration may be related also to a stronger deep source of seeping hydrocarbons, which provides better perspectives for hydrocarbon exploration of that area, in which hydrocarbons ascend faster towards the near-surface zone.

The analytical results demonstrated the dominance of alkanes over alkenes expressed by both the absolute concentrations (Table 1) and the relatively high values of ethane/ ethylene ratio $\left(\mathrm{C}_{2} / \mathrm{C}_{2=}\right)$ (Fig. 4). Taking into consideration that measurements were performed in a short time span and under stable atmospheric conditions as well as accepting the theory proposed by Saunders et al. (1999), it is concluded so far that in the study area, is dominated by the active and mixed microseepage of alkanes from petroleum generation

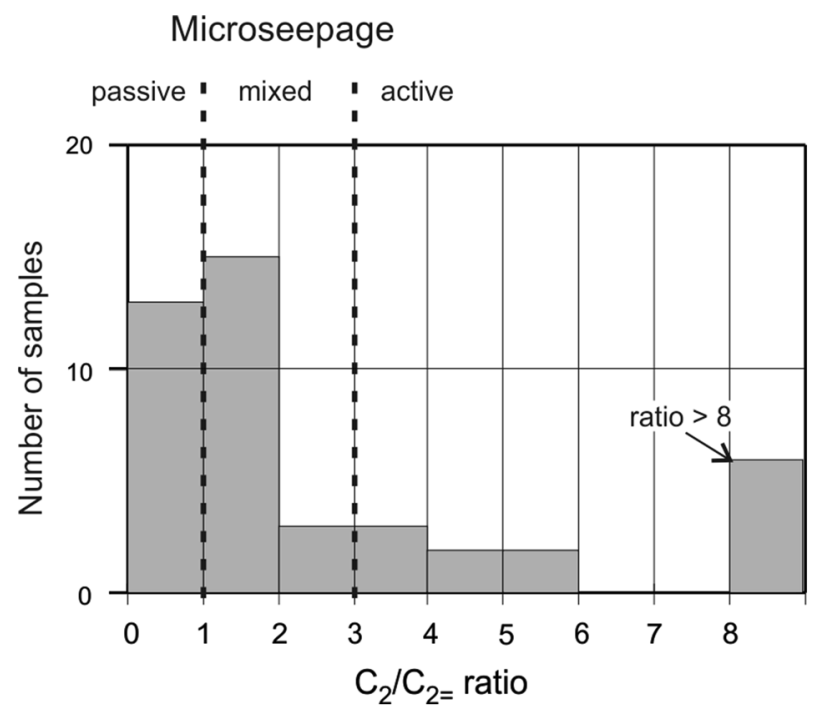

Fig. 4 Statistical distribution of $\mathrm{C}_{2} / \mathrm{C}_{2=}$ ratio values
Table 2 Principal statistical parameters of alkenes and non-hydrocarbon compounds concentrations in analyzed soil gas samples

\begin{tabular}{|c|c|c|c|c|c|c|c|c|}
\hline \multirow[t]{2}{*}{ Statistical parameters } & \multicolumn{3}{|c|}{ Alkenes } & \multirow{2}{*}{$\begin{array}{l}\text { Total alk- } \\
\text { enes } \mathrm{C}_{2}-\mathrm{C}_{4}\end{array}$} & \multirow[t]{2}{*}{$\mathrm{H}_{2}{ }^{\mathrm{b}}$} & \multirow[t]{2}{*}{$\mathrm{O}_{2}{ }^{\mathrm{b}}$} & \multirow[t]{2}{*}{$\mathrm{N}_{2}^{\mathrm{b}}$} & \multirow[t]{2}{*}{$\mathrm{CO}_{2}{ }^{\mathrm{b}}$} \\
\hline & $\mathrm{C}_{2} \mathrm{H}_{4}$ & $\mathrm{C}_{3} \mathrm{H}_{6}$ & $1-\mathrm{C}_{4} \mathrm{H}_{8}$ & & & & & \\
\hline Minimum (ppm) & b.d.l & b.d.l & b.d.1 & b.d.1 & b.d.1 & 12.6 & 52.6 & 0.11 \\
\hline Maximum (ppm) & 0.647 & 0.125 & 0.060 & 0.772 & 0.089 & 20.1 & 84.5 & 3.31 \\
\hline Median (ppm) & 0.012 & b.d.1 & b.d.l & 0.013 & b.d.1 & 18.4 & 79.5 & 0.47 \\
\hline Mean (ppm) & 0.052 & 0.010 & 0.002 & 0.064 & 0.01 & 18.9 & 80.3 & 0.67 \\
\hline Standard deviation (ppm) & 0.118 & 0.027 & 0.008 & 0.147 & 0.017 & 1.61 & 4.01 & 0.56 \\
\hline Skewness (ppm) & 3.318 & 3.056 & 5.419 & 3.239 & 2.52 & -1.8 & -4.46 & 2.07 \\
\hline Percentage of samples $(\%)^{\mathrm{a}}$ & 59.4 & 20.8 & 7.3 & 64.6 & 42.4 & 100 & 100 & 100 \\
\hline
\end{tabular}

b.d.l. below detection limit

${ }^{\text {a } P e r c e n t a g e ~ o f ~ s a m p l e s ~ w i t h ~ c o n c e n t r a t i o n ~ o f ~ g i v e n ~ c o m p o n e n t ~ o v e r ~ d e t e c t i o n ~ l i m i t ~}$

${ }^{\mathrm{b}}$ Minimum. maximum. median. mean, standard deviation and skewness value in vol\% 
and/or accumulations higher in the geologic section towards the Earth's surface (Fig. 4).

The concentrations of carbon dioxide in the analyzed samples varied from 0.11 to $3.31 \mathrm{vol} \%$. This dataset revealed relatively small difference between mean and median values, and low standard deviation (Table 2). Hydrogen was detected in $42 \%$ of analyzed samples with the maximum concentrations up to $0.1 \mathrm{vol} \%$ Statistical parameters of hydrogen and carbon dioxide sets showed anomalous concentrations. Unfortunately, these two components of soil gas are difficult to interpret due to their polygenetic character (Waleńczak 1987; Savary and Pagel 1997; Pallasser 2000; Head et al. 2003; Dolfing et al. 2008). Concentrations of oxygen varied from 12.6 to $20.1 \mathrm{vol} \%$ and those of nitrogen changed from 52.6 to $84.5 \mathrm{vol} \%$.

The determined geochemical background values were: methane-2.3 ppm, total alkanes- $0.007 \mathrm{ppm}$, total alkenes-0.01 ppm, hydrogen-0.005 vol\%, and carbon dioxide $-0.31 \mathrm{vol} \%$.

The relationships between ethane and propane are commonly applied to recognition of the type of deep petroleum accumulations (gas, oil and condensate). Usually, the ethane/ propane ratio $\left(\mathrm{C}_{2} / \mathrm{C}_{3}\right)$ is an indicator. If the ethane distinctly prevails over the propane the source accumulation is gaseous. If the ethane concentrations are only slightly higher or both hydrocarbons show similar concentrations, it can be concluded that the source accumulation contains oil.

The histogram of $\mathrm{C}_{2} / \mathrm{C}_{3}$ values is right-skewed, with 1-2 modal class (Fig. 5). Distribution of these values referred to the plot developed by Nikanov (1971) demonstrates the dominance of oil and oil-condensate deep accumulations in the study area (Fig. 5).

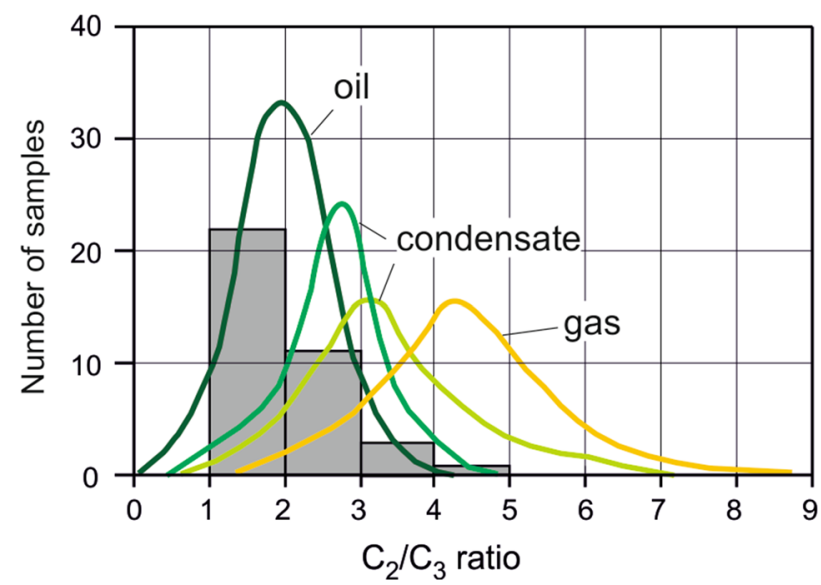

Fig. 5 Histogram of $\mathrm{C}_{2} / \mathrm{C}_{3}$ against the curves illustrating the character of deep hydrocarbon accumulations. Construction of curves based upon distribution of $\mathrm{C}_{2} / \mathrm{C}_{3}$ ratios in world hydrocarbon deposits (after Nikanov 1971)

\section{Statistical characterization of indirect geochemical indices}

The magnetic susceptibility values of soil samples changed within the range of $3.6-21.5 \times 10^{-8} \mathrm{~m}^{3} / \mathrm{kg}$. Difference between the mean and the median values was relatively low and the standard deviation was 3.7 , which suggests relatively small number of anomalous values.

The percentage of calcium carbonate in studied soils varied from 0.02 to $29.92 \mathrm{wt} \%$. The mean value was higher by one order of magnitude than the median and the standard deviation was 3.15 (Table 3). These parameters indicate the presence of anomalous values in the dataset.

The $\mathrm{pH}$ values changed from 4.5 to 8.3 and the mean $\mathrm{pH}-6.3$ - was equal to the median. Hence, the distribution of $\mathrm{pH}$ values was close to normal, as confirmed by low skewness. The standard deviation was 0.75 (Table 3). Such parameters point out to a small number of anomalous values. It must be noticed that anomalous $\mathrm{pH}$ values indicate either acid (low $\mathrm{pH}$ ) or alkaline (high $\mathrm{pH}$ ) soil conditions.

The highest skewness was calculated for calcium carbonate distribution, whereas the lowest one was found for $\mathrm{pH}$ histogram (Table 3). However, the low skewness of $\mathrm{pH}$ is also due to $\mathrm{pH}$ units being logarithmic units.

The magnetic susceptibility values revealed unimodal, right-skewed distribution with the modal class ranging from 4 to $6 \times 10^{-8} \mathrm{~m}^{3} / \mathrm{kg}$ (Fig. $6 \mathrm{a}$ ).

The calcium carbonate concentrations showed unimodal, right-skewed distribution with an anomalous tail and modal class ranging from 0.04 to $0.08 \mathrm{wt} \%$ (Fig. 6b).

The $\mathrm{pH}$ values had unimodal distribution with anomalous tail and modal class ranging from 6 to 6.5 (Fig. 6c).

Distributions of calcium carbonate contents, magnetic susceptibility and $\mathrm{pH}$ values are similar, and that of $\mathrm{pH}$ is closest to a normal distribution.

Background values calculated for calcium carbonate content, magnetic susceptibility and $\mathrm{pH}$ are: $0.06 \mathrm{wt} \%$, $6.53 \times 10^{-8} \mathrm{~m}^{3} / \mathrm{kg}$ and 6.1 , respectively.

Table 3 Principal statistical parameters of calcite contents, magnetic susceptibility and $\mathrm{pH}$ values in sampled soils

\begin{tabular}{lccc}
\hline Statistical parameters & \multicolumn{3}{l}{ Indirect geochemical indices } \\
\cline { 2 - 4 } & $\begin{array}{l}\text { Magnetic suscepti- } \\
\text { bility }\left(\chi \bullet 10^{-8} \mathrm{~m}^{3} / \mathrm{kg}\right)\end{array}$ & $\mathrm{CaCO}_{3}(\mathrm{wt} \%)$ & $\mathrm{pH}$ \\
\hline Minimum & 3.6 & 0.02 & 4.5 \\
Maximum & 21.5 & 29.92 & 8.3 \\
Median & 7.5 & 0.08 & 6.3 \\
Mean & 8.5 & 0.52 & 6.3 \\
Standard deviation & 3.7 & 3.15 & 0.8 \\
Skewness & 1.2 & 8.92 & 0.4
\end{tabular}



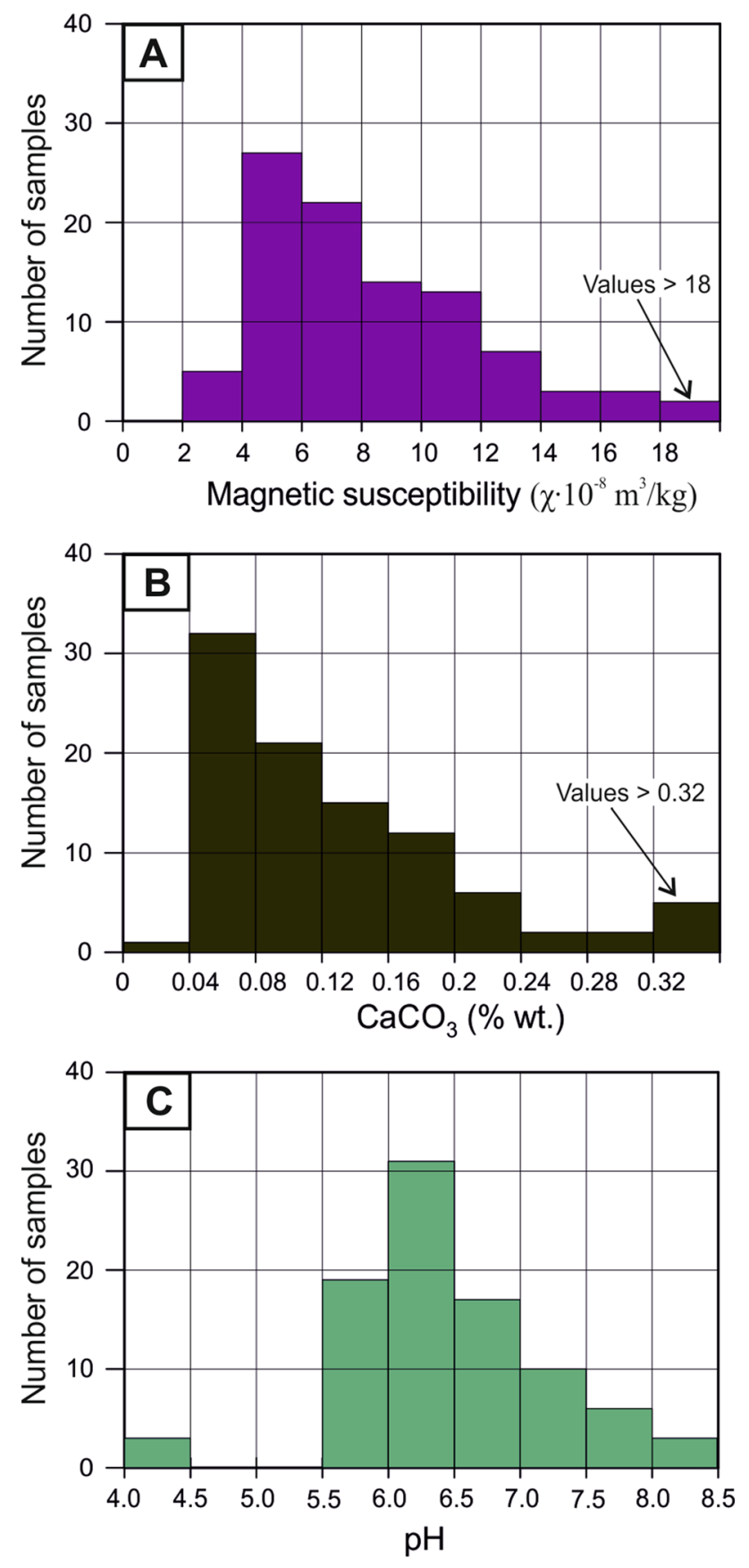

Fig. 6 Statistical distributions of magnetic susceptibility (a), calcium carbonate content (b) and $\mathrm{pH}$ values (c)

\section{Evaluation of correlations between geochemical indices calculated for the study area}

Among all geochemical indices calculated for the near surface zone in the study area, the strongest statistical correlation occurs between concentrations of methane and total alkanes $\mathrm{C}_{2}-\mathrm{C}_{5}$ (Table 4), as documented by high coefficient of determination $R^{2}=0.82$. It must be emphasized that anomalous concentrations of alkanes heavier than methane are the most important geochemical indicator of the presence of hydrocarbon accumulations. Our results allow to conclude that, despite its polygenetic character, methane is also an indicator of deep hydrocarbon accumulations. Correlation of total alkanes $\mathrm{C}_{2}-\mathrm{C}_{5}$ and total alkenes $\mathrm{C}_{2}-\mathrm{C}_{4}$ is moderate (Table 4) but still evident. This suggests that both hydrocarbon groups do not originate from a common deep source although alkenes and alkanes partly coexist. Among non-hydrocarbon components of soil gas, hydrogen shows generally higher correlation coefficients with hydrocarbons than carbon dioxide. This is due to the fact that carbon dioxide is easily produced as a result of the natural oxidation of organic matter in the soil (Kirchman 2012). Poor negative correlation between methane and carbon dioxide implies that in the study area, microbial oxidation of methane is absent in the near surface zone (Table 4).

The relatively high values of coefficient of determination occur between all alkanes (Table 5): from $R^{2}=0.7$ for methane-propane and methane- $i$-butane up to $R^{2}=0.95$ for ethane-propane pairs. It is remarkable that such high ethane-propane correlation clearly indicates their common source. Hence, the study area seems to be dominated by a single hydrocarbon-accumulating horizon.

The correlation between analyzed alkanes and alkenes is very low (Table 5), which confirms the earlier conclusion concerning their origin from different sources. Among alkenes, the highest coefficient of determination was found for ethylene and propylene $\left(R^{2}=0.79\right)$, which suggests that the process (or processes) controlling their generation and/ or migration to the near-surface zone is/are similar. The proportional occurrence of ethylene and propylene concentrations in soil gas samples is most likely the result of the first stage of microbial oxidation of ethane and propane (Klusman 2009). Another reason for the presence of ethylene and propylene in soil gas samples may be the breakdown of ethane and propane by some yet-undetermined process during their migration to the surface (Saunders et al. 1999; Jones et al. 2000).

The scatterplots of analyzed indirect geochemical indices reveal the lack of pronounced mathematical correlations. The highest coefficient of determination $\left(R^{2}=0.29\right)$ was found for $\mathrm{pH}$ and magnetic susceptibility, which may suggest that the presence of ferrimagnetic minerals somehow influences the $\mathrm{pH}$ values (Table 4).

Also the indirect and direct geochemical indices do not reveal mathematical correlations (Table 4), which presumably results from the fact that changes of hydrocarbon concentrations in the soil gas are caused by their recent migration from deep sources to the near-surface zone. On the contrary, the secondary changes of mineral composition of soils recorded by indirect geochemical indices result from long-lasting hydrocarbon migration during geologic time 
Table 4 Coefficients of determination $\left(R^{2}\right)$ for logarithmized values of hydrocarbon and non-hydrocarbon gaseous indices, and indirect geochemical indices

\begin{tabular}{|c|c|c|c|c|c|c|c|c|}
\hline Component $\left(\log _{10}\right)$ & Methane & $\begin{array}{l}\text { Total } \mathrm{C}_{2}-\mathrm{C}_{5} \\
\text { alkanes }\end{array}$ & $\begin{array}{l}\text { Total } \mathrm{C}_{2}-\mathrm{C}_{4} \\
\text { alkenes }\end{array}$ & Carbon dioxide & Hydrogen & Magnetic suscep & $\begin{array}{l}\text { Calcium } \\
\text { carbonate }\end{array}$ & $\mathrm{pH}$ \\
\hline Methane & 1 & 0.82 & 0.33 & 0.01 & 0.23 & 0.01 & 0.01 & 0.01 \\
\hline Total $\mathrm{C}_{2}-\mathrm{C}_{5}$ alkanes & & 1 & 0.45 & 0.01 & 0.18 & 0.09 & 0.02 & - \\
\hline Total $\mathrm{C}_{2}-\mathrm{C}_{4}$ alkenes & & & 1 & 0.04 & 0.31 & 0.03 & 0.07 & 0.02 \\
\hline Carbon dioxide & & & & 1 & - & 0.01 & 0.01 & - \\
\hline Hydrogen & & & & & 1 & 0.01 & 0.09 & 0.03 \\
\hline Magnetic susceptibility & & & & & & 1 & 0.06 & 0.29 \\
\hline Calcium carbonate & & & & & & & 1 & 0.16 \\
\hline $\mathrm{pH}$ & & & & & & & & 1 \\
\hline
\end{tabular}

Table 5 Coefficients of determination $\left(R^{2}\right)$ for logarithmized values of alkanes and alkenes concentrations analyzed in soil gas samples

\begin{tabular}{|c|c|c|c|c|c|c|c|c|}
\hline Component $\left(\log _{10}\right)$ & Methane & Ethane & Propane & $i$-Butane & $n$-Butane & Ethylene & Propylene & 1-Butene \\
\hline Methane & 1 & 0.86 & 0.70 & 0.70 & 0.73 & 0.35 & 0.21 & 0.01 \\
\hline Ethane & & 1 & 0.95 & 0.79 & 0.83 & 0.46 & 0.25 & 0.11 \\
\hline Propane & & & 1 & 0.75 & 0.82 & 0.25 & 0.18 & 0.04 \\
\hline$i$-Butane & & & & 1 & 0.89 & 0.01 & 0.01 & 0.01 \\
\hline n-Butane & & & & & 1 & 0.07 & 0.02 & 0.38 \\
\hline Ethylene & & & & & & 1 & 0.79 & 0.01 \\
\hline Propylene & & & & & & & 1 & 0.20 \\
\hline 1-Butene & & & & & & & & 1 \\
\hline
\end{tabular}

(fossil anomalies). Hence, the active zones of hydrocarbon migration might have evolved in the past.

\section{Analysis of changes of direct and indirect geochemical indices referred to geological-seismic cross-section}

The sets of analyzed concentrations of total alkanes $\mathrm{C}_{2}-\mathrm{C}_{5}$, methane, total alkenes $\mathrm{C}_{2}-\mathrm{C}_{4}$, hydrogen, carbon dioxide, and calcium carbonate content as well as the measured values of magnetic susceptibility and $\mathrm{pH}$ were normalized in relation to background values of these parameters determined separately with the iteration method (Sechman and Dzieniewicz 2011). Normalization allowed us to objectively identify the anomalous values and to compare the changes of particular geochemical indices. Additionally, the normalized values of geochemical indices were subjected to filtration with the three-point filter (Sechman and Dzieniewicz 2011). Although such filtration distorts to some extent the recorded data, it generally facilitates their interpretation. Changes of normalized and filtered concentrations were presented as diagrams and referred to the geological-seismic cross-section (Fig. 7).

The changes of normalized and filtered values of calcium carbonate content, magnetic susceptibility and $\mathrm{pH}$ along the sampling line (Fig. 7b) reveal some similarities. Particularly similar are changes of calcium carbonate contents and magnetic susceptibility values. Insofar as the changes of calcium carbonate and magnetic minerals contents are determined mostly by the processes operating along the hydrocarbon migration pathways from deep accumulations towards to near-surface zone (Saunders et al. 1999), it seems that $\mathrm{pH}$ values are controlled primarily by surface factors, as suggested by Klusman (1993) and Tedesco (1995). It is even more probable, because $\mathrm{pH}$ values measured in our soil samples are relatively uniform. It must be emphasized that our soil samples are representative, i.e. these were collected in the same way from the same depth interval. Moreover, soils in the study area are generally homogenous. Thus, relatively low diversity of $\mathrm{pH}$ values may suggest that hydrocarbon flux did not influence the $\mathrm{pH}$ of analyzed soils (Fig. 7).

The recent studies on magnetic susceptibility, calcium carbonate content and $\mathrm{pH}$ in soils from world petroleum basins reveal that these results may provide additional information suitable for hydrocarbon exploration. Particularly, the investigations of magnetic susceptibility of soils over the hydrocarbon plays carried on in various parts of the world (Saunders et al. 1991; Liu et al. 2004) demonstrated the presence of hydrocarbon and magnetic susceptibility anomalies over the petroleum accumulations at depths. Also, analyses of carbonate minerals distribution showed their anomalous contents in the near-surface 


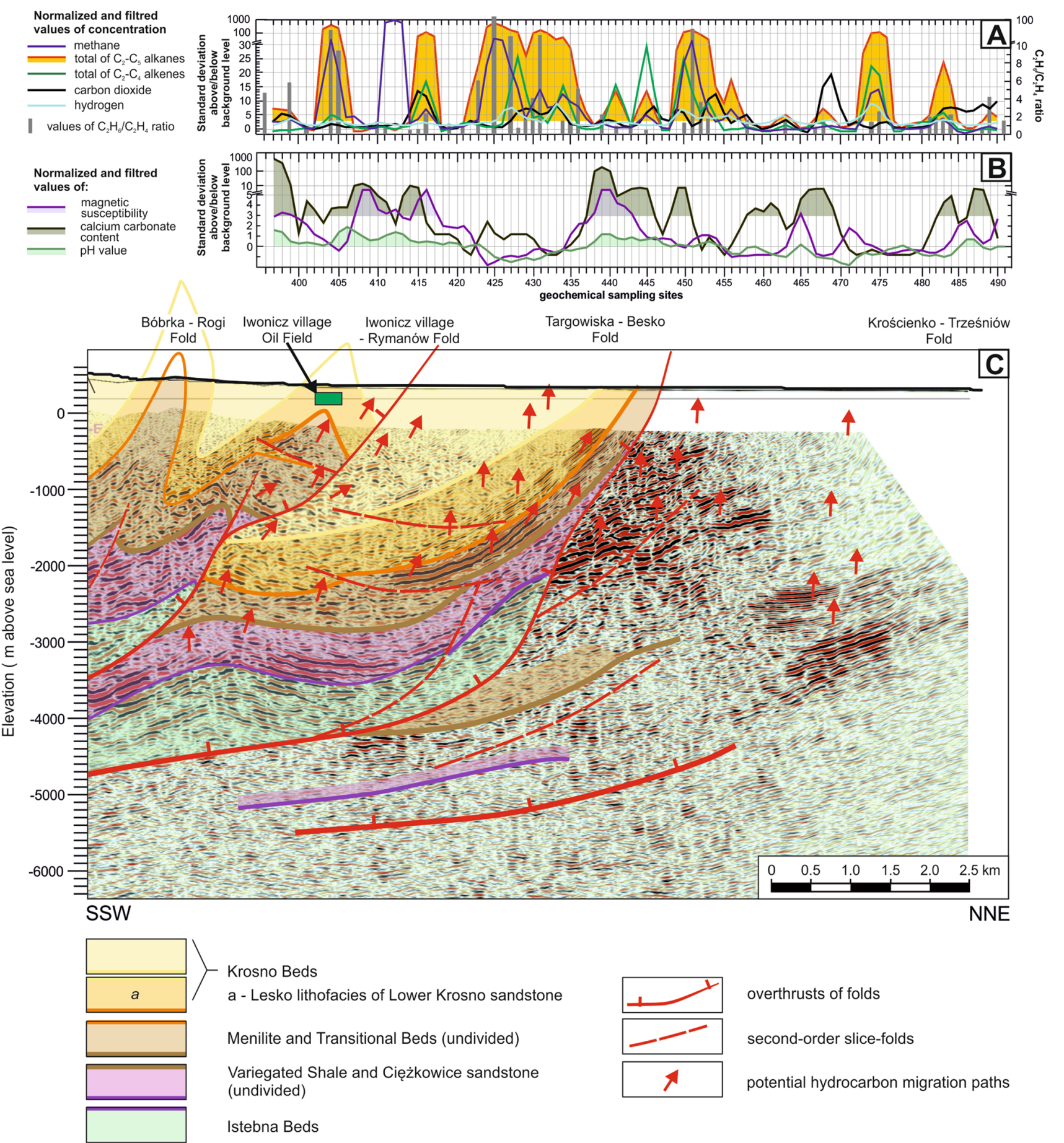

Fig. 7 Changes of normalized and filtered values of surface geochemical indices referred to geological-seismic cross-section. Interpretation of seismic section after Kuśmierek et al. (2016a, b), modified

zone above the petroleum deposits (Duchscherer 1984; Horvitz 1985; Duchscherer and Mashburn 1987). On the contrary, $\mathrm{pH}$ measurements of soils did not indicate the links between hydrocarbon microseepage and soil $\mathrm{pH}$ in studied localities (Klusman 1993; Tedesco 1995), although the "haloe" effect was sometimes noticed in the wells.
According to Klusman (1993) and Tedesco (1995), soil $\mathrm{pH}$ values used in petroleum exploration should always be integrated with the results of other geochemical methods. Moreover, it must be remembered that among geochemical indicators, soil $\mathrm{pH}$ is most of all affected by the surface, 
atmospheric and anthropogenic factors, as e.g. soil deacidification by liming, which always increases the $\mathrm{pH}$.

The latest geochemical survey run in the Carpathians (Twaróg et al. 2018a) revealed the decreasing calcium carbonate contents in soils from the zones of anomalous concentrations of total alkanes $\mathrm{C}_{2}-\mathrm{C}_{5}$ and total alkenes $\mathrm{C}_{2}-\mathrm{C}_{4}$ in soil gases. However, distribution of $\mathrm{pH}$ values did not show any link to the remaining geochemical indices determined for studied sampling line.

Generally, the distribution of anomalies of calcium carbonate content and magnetic minerals is similar (Fig. 7). Also, subtle differences in $\mathrm{pH}$ values partly follow these anomalies, hence, a trend is noticeable of $\mathrm{pH}$ changes conformable with those of calcium carbonate and magnetic minerals contents.

The changes of indirect geochemical indices values are opposite to the changes of total alkanes $\mathrm{C}_{2}-\mathrm{C}_{5}$ concentrations in soil gas, i.e. the indices values decrease where the alkane concentrations increase. The exception is the end-segment of the sampling line, between sites Nos. 396 and 417 (Fig. 7a, b). The segment between sites 396 and 399 shows anomalous contents of magnetic minerals and increased amounts of calcium carbonate content but anomalous concentrations of alkanes $\mathrm{C}_{2}-\mathrm{C}_{5}$ are not evident there. Generally, in all the sampling sites located in the area of the Iwonicz-Rymanów Fold, increased contents of calcium carbonate and ferrimagnetic minerals are detected but anomalies of alkanes $\mathrm{C}_{2}-\mathrm{C}_{5}$ occur only at a few sites. Simultaneously, at the same sites, high values of ethane/ethylene ratio are noticed, which indicates active hydrocarbon migration from a deep-seated source. Such geochemical pattern of soils over the Iwonicz-Rymanów Fold demonstrates that biochemical processes operating within this structure might have resulted in secondary mineralization and pore cementation in the near-surface zone. This, in turn, prevented more active hydrocarbon migration from the oil and gas fields. Secondary mineralization phenomena can occur in the nearsurface zone as well as at greater depths. These phenomena are confirmed by the presence of numerous calcite veins and traces of crude oil in the drilling core from the Ry-1 borehole (PGI 2019), located on the extension of Iwonicz Vilage-Rymanów Fold (Fig. 2).

In the area of the Targowiska-Besko Fold, no calcium carbonate content and/or magnetic susceptibility anomalies were observed within the anomalous zone of total alkanes $\mathrm{C}_{2}-\mathrm{C}_{5}$ identified between the sampling sites Nos. 423 and 434. Presumably, the dislocated sediments of the MeniliteKrosno Series provided suitable hydrocarbon migration pathway, as confirmed by relatively high ethane/ethylene ratio. On the contrary, no remarkable total alkanes $\mathrm{C}_{2}-\mathrm{C}_{5}$ anomalies were observed within the culmination of the Targowiska-Besko Fold. Low values of ethane/ethylene ratio, indicating the decreased hydrocarbon migration, may support the concept that lowered permeability of rocks in that zone was related to precipitation of calcium carbonate and magnetic minerals within the high-angle layers of the Menilite rocks and the thick-bedded sandstones. Along the outcrops of these sediments, the initially intensive hydrocarbon migration might have been slowed down due to precipitation of calcium carbonate and formation of magnetic minerals (Fig. 7c). The further tectonic deformations resulted in generation of smaller fracture and fault systems, which might have produced the new hydrocarbon migration pathways. Hence, the changes of alkane concentrations form a kind of"haloe" over the culmination of the TargowiskaBesko Fold. Consequently, in the central part of this zone, both the conventional and the unconventional hydrocarbon accumulations (Kozimor et al. 2017) can be expected within the Krosno Sandstones and/or within the Menilite and the Transitional beds. Such a concept is confirmed by anomalous seismic signature observed in that zone (Fig. 7c).

The other alkane anomalies determined along the sampling line, between the sites Nos. 450-453 and 482-484, do not follow the anomalies of indirect geochemical indices (i.e. contents of calcium carbonate and magnetic minerals, and $\mathrm{pH}$ values). Within the area of the Krościenko-Trześniów Fold, the anomalous contents of calcium carbonate and magnetic minerals correspond to low values of ethane/ethylene ratio but not to the interpreted anomalous seismic image.

\section{Summary and conclusions}

The experimental surface geochemical survey performed along the sampling line in the Krosno-Besko area (eastern part of the Polish Outer Carpathians) included the analyses of molecular composition of soil gases and calcium carbonate contents as well as the measurements of magnetic susceptibility and $\mathrm{pH}$ of soil samples. The research project aimed to evaluate the relationships between distributions of direct and indirect geochemical indices, and to integrate such data with the geological and seismic models to appraisal of petroleum potential of the study area. The sampling supplied 96 soil gas samples collected at $1.2 \mathrm{~m}$ depth and 96 soil samples taken from depth interval $0.7-0.8 \mathrm{~m}$.

The results revealed large variations of both the concentrations of various hydrocarbon and non-hydrocarbon gas components, and the values of various indirect geochemical indices. The highest variation was found for methane concentrations (from 1.1 to $2100 \mathrm{ppm}$ ). The maximum concentrations of total alkanes $\mathrm{C}_{2}-\mathrm{C}_{5}$ and total alkenes $\mathrm{C}_{2}-\mathrm{C}_{4}$ and hydrogen were: $10.43 \mathrm{ppm}, 0.772 \mathrm{ppm}$, and $0.089 \mathrm{vol} \%$, respectively. Concentrations of carbon dioxide varied from: 0.113 to $3.312 \mathrm{vol} \%$. The measured values of magnetic susceptibility varied from 3.6 to $21.5 \times 10^{-8} \mathrm{~m}^{3} / \mathrm{kg}$. The contents of calcite in analyzed soils changed from 0.02 to 29.92 
$\mathrm{wt} \%$ and the $\mathrm{pH}$ values measured in soil solutions obtained from collected soils changed from 4.5 to 8.3 .

The analysis of geochemical indices indicated diversified hydrocarbon migration from deep oil and oil-condensate accumulations. Strong correlations between all alkanes advocated the dominance of a single, hydrocarbon-saturated horizon. Interpretation of the relationships between gaseous alkanes and alkenes showed that strong alkane anomalies are correlated with strong alkene anomalies. However, alkanes and alkenes did not show strong correlations, which supports the opinion that they did not originate from the same hydrocarbon accumulations or they undergo complicated geochemical reactions in different migration pathways.

Our study revealed the lack of correlation between the direct and the indirect geochemical indices. This seems to be an effect of various mechanisms governing the appearance of such anomalies. The changes of hydrocarbon concentrations in the soil gas resulted from their recent migration from deep accumulations to the near-surface zone. However, the secondary changes of mineral composition of soils disclosed by the indirect methods were controlled by hydrocarbon migration extended during geologic time, which might have shifted the location of active hydrocarbon migration pathways.

The analysis of distribution patterns of normalized and filtered values of both the direct and indirect geochemical indices was referred to the geological-seismic cross-sections, which enabled us to propose conclusions about hydrocarbon migration from deep-seated accumulations. Generally, the concentrations of total alkanes $\mathrm{C}_{2}-\mathrm{C}_{5}$ in the soil gas are inversely proportional to the values of indirect geochemical indices, i.e. the decreasing concentrations of alkanes correspond to the increasing values of the indirect indices. Such relationship may reflect the presence of secondary mineralization and the resulting cementation of pore spaces in both the overburden formations and the near-surface zone. Hence, some existing migration pathways might have become sealed and the gaseous hydrocarbons had to avoid such secondary diagenetic screens in their seepage to the near-surface zone, giving rise to characteristic "haloes" of alkanes anomalies. A "haloe" was encountered over the culmination of the Targowiska-Besko Fold. It indicates the existence of conventional and/or unconventional petroleum accumulations within the Krosno Sandstones and/or the Menilite, and the Transitional beds.

The comprehensive interpretation of the results of surface geochemical survey obtained with both the direct (free gas) and indirect (magnetic susceptibility, calcite content, $\mathrm{pH}$ ) methods allows the researcher to better understand the complexity of hydrocarbon migration through complicated geological structures and provides more detailed information about the position and character of deep hydrocarbon accumulations.
Acknowledgements The authors thank Victor Jones and anonymous reviewer for valuable comments and suggestions that have improved the quality of our publication. The research was carried on partly within the ShaleCarp task of the Blue Gas II project financed by the National Center for Research and Development, grant No. BG/ShaleCarp/14, partly within the Dean's Grant No. 15.11.140.651 financed by the Faculty of Geology, Geophysics and Environmental Protection, AGH University of Science and Technology in Kraków and partly within the statutory research activity of the Department of Fossil Fuels of that Faculty, Grant No. 16.16.140.315.

Open Access This article is licensed under a Creative Commons Attribution 4.0 International License, which permits use, sharing, adaptation, distribution and reproduction in any medium or format, as long as you give appropriate credit to the original author(s) and the source, provide a link to the Creative Commons licence, and indicate if changes were made. The images or other third party material in this article are included in the article's Creative Commons licence, unless indicated otherwise in a credit line to the material. If material is not included in the article's Creative Commons licence and your intended use is not permitted by statutory regulation or exceeds the permitted use, you will need to obtain permission directly from the copyright holder. To view a copy of this licence, visit http://creativecommons.org/licenses/by/4.0/.

\section{References}

Boyer Ch, Clark B, Jochen V, Lewis R, Miller CK (2011) Shale gas: a global resource. Oilfield Rev 23(3):28-39

Dolfing J, Larter SR, Head IM (2008) Thermodynamic constraints on methanogenic crude oil biodegradation. ISME J 2(4):442-452

Donovan TJ (1974) Petroleum microseepage at Cement, Oklahoma: evidence and mechanism. AAPG Bull 58:429-446

Duchscherer W (1984) Geochemical hydrocarbon prospecting: with case histories. PennWell Corporation, Tulsa

Duchscherer W, Mashburn L (1987) Application of delta-C method to Caldonia and Walbanger fields Elbert Country, Colorado. AAPG Bull 3:15-39

Dziadzio P, Borys Z, Kuk S, Masłowski E, Probulski J, Pietrusiak M, Górka A, Moryc J, Baszkiewicz A, Karnkowski P, Karnkowski PH, Pietrusiak M (2006) Hydrocarbon resources of the Polish Outer Carpathians-reservoir parameters, trap types, and selected hydrocarbon fields: a stratigraphic review. In: Golonka J, Picha FJ (eds) The Carpathians and their foreland: geology and hydrocarbon resources. The American Association of Petroleum Geologists, Memoir 84, Tulsa, pp 259-291

Elmore RD, Engel MH, Crawford L, Nick K, Imbus S, Sofer Z (1987) Evidence for a relationship between hydrocarbons and authigenic magnetite. Nature 325:428-430

Gay SP (1992) Epigenetic versus syngenetic magnetite as a cause of magnetic anomalies. Geophysics 57(1):60-68

Harbert W, Jones VT, Izzo J, Anderson TH (2006) Analysis of light hydrocarbons in soil gases, Lost River region, West Virginia: relation to stratigraphy and geological structures. AAPG Bull 90(5):715-734

Head IM, Jones DM, Larter SR (2003) Biological activity in the deep subsurface and the origin of heavy oil. Nature 426:344-352

Horvitz L (1985) Geochemical exploration for petroleum. Science 229(4716):821-827

Jankowski L, Kopciowski R, Ryłko W (2004) Geological map of the Outer Carpathians: borderland of Poland, Ukraine and Slovakia (1:200 000). Wydawnictwo Państwowego Instytutu Geologicznego, Warszawa 
Jones VT, Drozd RJ (1983) Prediction of oil or gas potential by nearsurface geochemistry. AAPG Bull 67(6):932-952

Jones VT, Matthews MD, Richers DM (2000) Light hydrocarbons for petroleum and gas prospecting. In: Hale M (ed) Handbook of exploration geochemistry, vol 7, pp 133-212

Jucha S (1969) Jasło shales, their importance for stratigraphy and sedimentology of the Menilite-Krosno series. Pr Geol PAN 128 (in Polish with Russian and French abstract)

Karnkowski PH (2007) Petroleum provinces in Poland. Prz Geol 55:1061-1067

Karnkowski PH, Matyasik I (2016) Critical elements of petroleum systems in the sedimentary basins in Poland. Prz Geol 64(9):639-649

Kirchman DL (2012) Processes in microbial ecology. Oxford University Press, Oxford, pp 1-328

Klusman RW (1993) Soil gas and related methods for natural resource exploration. Wiley, Chichester, pp 1-495

Klusman RW (2006) Detailed compositional analysis of gas seepage at the National Carbon Storage Test Site, Teapot Dome, Wyoming, USA. Appl Geochem 21(9):1498-1521

Klusman RW (2009) Transport of ultratrace reduced gases and particulate, near-surface oxidation, metal deposition and adsorption. Geochem Explor Environ Anal 9:203-213

Klusman RW (2011) Comparison of surface and near-surface geochemical methods for detection of gas microseepage from carbon dioxide sequestration. Int J Greenhouse Gas Control 5(6):1369-1392

Kotarba MJ, Koltun YV (2006) The origin and habitat of hydrocarbons of the Polish and Ukrainian parts of the Carpathian Province. In: Golonka J, Picha FJ (eds) The Carpathians and their foreland: geology and hydrocarbon resources. The American Association of Petroleum Geologists, Memoir 84, Tulsa, pp 395-442

Kotarba MJ, Więcław D, Koltun YV, Marynowski L, Kuśmierek J, Dudok IV (2007) Organic geochemical study and genetic correlation of natural gas, oil and Menilite source rocks in the area between San and Stryi rivers (Polish and Ukrainian Carpathians). Org Geochem 38:1431-1456

Kováč M, Márton E, Oszczypko N, Vojtko R, Hók J, Králiková S, Plašienka D, Klučiar T, Hudáčková N, Oszczypko-Clowes M (2017) Neogene palaeogeography and basin evolution of the Western Carpathians, Northern Pannonian domain and adjoining areas. Glob Planet Change 155:133-154

Kozimor T, Potera J, Nieć M (2017) Hybrid hydrocarbon accumulations (conventional accompanied by unconventional ones) and reporting of their resources. Prz Geol 65:643-649

Kuśmierek J (1990) Outline of geodynamics of Central Carpathian oil basin. Pr Geol KNG PAN 135:1-85 (in Polish with English abstract)

Kuśmierek J (2010) Subsurface structure and tectonic style of the NE Outer Carpathians (Poland) on the basis of integrated 2D interpretation of geological and geophysical images. Geol Carpath 61(1):71-85

Kuśmierek J, Baran U (2016) Structure and tectonic evolution of the NE segment of the Polish-Ukrainian Carpathians during the Late Cenozoic: subsurface cross-sections and palinspastic models. Geol Carpath 67(4):347-370

Kuśmierek J, Machowski G (2008) Oil seeps in the area of the eastern Polish Carpathians and their prognostic significance. Pr INiG Kraków 150:247-250 (in Polish with English abstract)

Kuśmierek J, Baran U, Machowski G (2016a) Geological interpretation of deep tectonics of folds and overthrusts in seismic sections in the Krosno-Besko area. ShaleCarp task of the Blue Gas II project (in Polish)

Kuśmierek J, Machowski G, Baran U (2016b) Seismic imaging of the tectonic style of the Central Carpathian Synclinorium in the Krosno-Besko area. Pr INiG Kraków 209:513-518 (in Polish with English abstract)
LeSchack LA, Van Alstine DR (2002) High-resolution ground-magnetic (HRGM) and radiometric surveys for hydrocarbon exploration: six case histories in Western Canada. In: Schumacher D, LeSchack LA (eds) Surface exploration case histories: Applications of geochemistry, magnetics, and remote sensing. AAPGSEG Studies in Geology No. 48 and SEG Geophysical References Series, vol 11, pp 67-156

Liu QS, Chan LS, Liu Q, Li H, Wang F, Zhang S, Xia X, Cheng T (2004) Relationship between magnetic anomalies and hydrocarbon microseepage above the Jingbian gas field, Ordos basin, China. AAPG Bull 88(2):241-251

Machel HG, Burton EA (1991) Causes and spatial distribution of anomalous magnetization in hydrocarbons seepage environments. AAPG Bull 75(12):1864-1876

Matthews MD (1996) Importance of sampling design and density in target recognition. In: Schumacher D, Abrams MA (eds) Hydrocarbon migration and its near-surface expression. The American Association of Petroleum Geologists, Memoir 66, Tulsa, pp 243-253

Matyasik I, Dziadzio P (2006) Reconstruction of petroleum systems based on integrated geochemical and geological investigations: selected examples from the Middle Outer Carpathians in Poland. In: Golonka J, Picha FJ (eds) The Carpathians and their foreland: geology and hydrocarbon resources. The American Association of Petroleum Geologists, Memoir 84, Tulsa, pp 497-518

Mørk MBE, Leith DA, Fanavoll S (2001) Origin of carbonatecemented beds on the Naglfar Dome, Vøring Basin, Norwegian Sea. Mar Petrol Geol 18(2):223-234

Nikanov VF (1971) Distribution of methane homologs in gas and oil fields. Akademija Nauk SSSR Doklady 206:234-246 (in Russian)

Oszczypko N, Ślączka A, Żytko K (2008) Tectonic subdivision of Poland: Polish Outer Carpathians and their foredeep. Prz Geol 56(10):927-935 (in Polish with English abstract)

Pallasser R (2000) Recognizing biodegradation in gas/oil accumulations through the $\mathrm{d}^{13} \mathrm{C}$ compositions of gas components. Org Geochem 31(12):1363-1373

Pawlewicz M (2204D) Total petroleum systems of the North Carpathian Province of Poland, Ukraine, Czech Republic, and Austria. U.S Geol Survey Bull 2204D:1-26

PGI (2019) Polish Geological Institute-National Research Institute, 2019 Boreholes in Central Geological Database (CBDG). https:// geoportal.pgi.gov.pl/otwory

Reynolds RL, Webring M, Grauch VJS, Tuttle M (1990) Magnetic forward models of cement oil field, Oklahoma, based on rock magnetic, geochemical and petrologic constraints. Geophysics $55: 344-353$

Roure F, Roca E, Sassi W (1993) The Neogene evolution of the outer Carpathian flysch units (Poland, Ukraine and Romania): kinematics of a foreland/fold-and-thrust belt system. Sediment Geol 86(1-2):177-201

Sassen R, McCabe Ch, Kyle JR, Chinn EW (1989) Deposition of magnetic pyrrhotite during alteration of crude oil and reduction of sulfate. Org Geochem 14(4):381-392

Saunders DF, Burson KR, Thompson CK (1991) Observed relation of soil magnetic susceptibility and soil gas hydrocarbon analyses to subsurface hydrocarbon accumulations (1). AAPG Bull 75:389-408

Saunders DF, Burson KR, Thompson CK (1999) Model for hydrocarbon microseepage and related near-surface alterations. AAPG Bull 83:170-185

Savary V, Pagel M (1997) The effects of water radiolysis on local redox conditions in the Oklo, Gabon, natural fission reactors 10 and 16. Geochim Cosmochim Acta 61(21):4479-4494

Schumacher D (1996) Hydrocarbon-induced alteration of soils and sediments. In: Schumacher D, Abrams MA (eds) Hydrocarbon 
migration and its near-surface expression. The American Association of Petroleum Geologists, Memoir 66, Tulsa, pp 71-89

Schumacher D (2017) Minimizing exploration risk: the impact of hydrocarbon microseepage surveys for distinguishing hydrocarbon-charged traps from traps without hydrocarbons. In: The American association of petroleum geologists annual meeting, Houston, Texas, United States, April 2-4

Sechman H (2012) Detailed compositional analysis of hydrocarbons in soil gases above multi-horizon petroleum deposits - A case study from western Poland. Appl Geochem 27(10):2130-2147

Sechman H, Dzieniewicz M (2009) Methane emission measurements in selected areas of the Polish Outer Carpathians. Geologia Kwartalnik AGH 35(4/1):129-153 (in Polish with English abstract)

Sechman H, Dzieniewicz M (2011) The example of background determination and mathematical processing of data from surface geochemical survey for the purposes of petroleum exploration. $\mathbf{J}$ Petrol Sci Eng 78(2):396-406

Sechman H, Dzieniewicz M, Liszka B (2012) Soil gas composition above gas deposits and perspective structures of the Carpathian Foredeep, SE Poland. Appl Geochem 27(1):197-210

Sechman H, Izydor G, Guzy P, Dzieniewicz M (2015) Surface geochemical exploration for hydrocarbons in the area of prospective structures of The Lublin Trough (Eastern Poland). Mar Petrol Geol 61:22-38

Sechman H, Kuśmierek J, Machowski G, Guzy P, Dzieniewicz M (2016) Surface geochemical anomalies in the vicinity of the Wańkowa Oil Field (SE Polish Carpathians). Ann Soc Geol Pol 86:219-235

Sechman H, Góra A, Twaróg A, Guzy P, Górska-Mruk E, Górecki W (2018) Near-surface geochemical anomalies integrated with seismic and well data over the contact of the Outer Carpathians and the Carpathian Foredeep (SE Poland). Geofluids. https://doi. org/10.1155/2018/7014324

Ślączka A, Krugłov S, Golonka J, Oszczypko N, Popadyuk I (2006) Geology and hydrocarbon resources of the Outer Carpathians, Poland, Slovakia, and Ukraine: general geology. In: Golonka J, Picha FJ (eds) The Carpathians and their foreland: geology and hydrocarbon resources. The American Association of Petroleum Geologists, Memoir 84, Tulsa, pp 221-258

Sokolov WA, Grigoriev GG (1962) Methods and results of gas geochemical survey. Gostoptiechizdat, Moskwa, pp 1-403 (in Russian)

Starzec K (2016) Development of a surface geological map in the Sobniów - Kombornia-Rogi concession area to identify key elements of the hydrocarbon generation, migration and accumulation processes. Geological map, scale 1:50 000. ShaleCarp task of the Blue Gas II project. GEOKRAK (in Polish)
Tedesco SA (1995) Surface geochemistry in petroleum exploration. Chapman \& Hall International Thomson Publishing Company, New York, pp 1-206

Telegina ZP, Cherkinskaya BS (1971) Possibility of the formation of unsaturated hydrocarbons during oxidation of saturated hydrocarbons by microorganisms. Results of development and testing of direct geochemical methods of finding deposits of oil and gas 10 . Nedra, Moscow, pp 61-64 (in Russian)

Twaróg A, Przybytek J, Ochman M, Guzy P, Góra A (2018) Results of surface geochemical survey conducted within Biecz AnticlinePolish Outer Carpathians. Science and technologies in geology, exploration and mining, Iss. 1.4, Mineral processing, oil and gas exploration. Sofia 18:757-758

Twaróg A, Stefaniuk M, Sechman H, Guzy P (2018) Integrated analysis of geoelectric and surface geochemical data for exploration of subsurface hydrocarbon accumulations (Carpathian Foredeep, SE Poland). J Petrol Sci Eng 167:524-537

U.S. EIA (2019) U.S. Energy Information Administration EIA (accessed on 29 July 2019), Tight Oil Remains the Leading Source of Future U.S. Crude Oil Production. Washington, DC, 2018. https://www.eia.gov/todayinenergy/detail.php?id=35052

Waleńczak Z (1987) Geochemia organiczna. Wydawnictwo Geologiczne, Warszawa (in Polish)

Wojas A (2009) The investigations of magnetic susceptibility of urban soils in Kraków. Geologia Kwartalnik AGH 35(2/1):489-496 (in Polish with English abstract)

Wojas A (2017) The magnetic susceptibility of soils in Krakow, southern Poland. Acta Geophys 65(3):453-463

Wojas A, Rolirat A, Grabowska T (2010) Reconnaissance investigations of magnetic susceptibility of subsoil formation in the selected areas in southern Poland. Geol Kwartalnik AGH 36(2):241-262 (in Polish with English abstract)

Wolleben JA, Greenlee DW (2002) Successful application of micromagnetic data to focus hydrocarbon exploration. In: Schumacher D, LeSchack LA (eds) Surface exploration case histories: applications of geochemistry, magnetics, and remote sensing. AAPGSEG studies in geology No. 48 and SEG Geophysical References Series, vol 11, pp 175-191

Zou C (ed) (2013) Unconventional petroleum geology. Elsevier Inc., New York, pp 1-373

Żytko K, Gucik S, Ryłko W, Oszczypko N, Zając R, Galicka I, Nemčok J, Eliáš M, Menćik E, Dvorak J, Stráník Z, Rakús M, Matejovská O (1989) Geological map of the western outer Carpathians and their foreland without Quaternary formations, 1:500 000. In: Poprawa D, Nemčok J (eds) Geological atlas of the western outer Carpathians and their foreland. Państwowy Instytut Geologiczny, Warszawa, pp 1988-1989 